\title{
SELECTION AND RANKING OF OCCUPATIONAL SAFETY INDICATORS BASED ON FUZZY AHP: A CASE STUDY IN ROAD CONSTRUCTION COMPANIES
}

\author{
G.L. J anackovic ${ }^{1 *}$, S.M. Savic ${ }^{2} \&$ M.S. Stankovic ${ }^{3}$ \\ Faculty of Occupational Safety \\ University of Nis, Nis, Serbia \\ 1.janackovic.goran@gmail.com, 22 suzanasav@gmail.com, 3miomir.stankovic@gmail.com
}

\begin{abstract}
This paper presents the factors, performance, and indicators of occupational safety, as well as a method to select and rank occupational safety indicators based on the expert evaluation method and the fuzzy analytic hierarchy process (fuzzy AHP). A case study is done on road construction companies in Serbia. The key safety performance indicators for the road construction industry are identified and ranked according to the results of a survey that included experts who assessed occupational safety risks in these companies. The case study confirmed that organisational factors have a dominant effect on the quality of the occupational health and safety management system in Serbian road construction companies.
\end{abstract}

\section{OPSOMMING}

Hierdie artikel toon die faktore, prestasies en aanwysers van beroepsveiligheid en ' $n$ metode om beroepsveiligheid aanwysers te kies en te rangskik. Die rangskikking van beroepsveiligheid aanwysers is gegrond op die deskundige evaluasie metode en die wasige analitiese hiërargie proses. 'n Gevalle studie is geloods op padkonstruksie maatskappye in Serwië. Die sleutel veiligheidsprestasieaanwysers is geïdentifiseer en rangskik volgens die resultate van ' $n$ opname onder deskundiges wat die beroepsveiligheid risiko's in hierdie maatskappye assesseer. Die gevalle studie het bevestig dat organisatoriesefaktore ' $n$ daadwerklike effek op die gehalte van die beroepsveiligheid bestuurstelsel in Serwiese padkonstruksie maatskappye het.

\footnotetext{
* Corresponding author
} 


\section{$1 \quad$ INTRODUCTION}

Injuries, occupational diseases, and illnesses related to work are negative consequences of human work activities. They represent a significant social and economic burden on individuals, employers, and society. For individuals, the effect is not just the physical pain and suffering, but is also the loss of part of a salary and the inability to maintain a standard of living.

Employers have significant costs associated with occupational injuries, diseases, and death. There are direct costs (payments to be made in cases of injury and illness of workers) and indirect costs (through the absence from work of injured or ill workers; other employees having to stop work because of accidents; and reduced production). According to a study conducted at Stanford University, indirect costs are 1.1 (for the most serious injuries) to 4.5 (for minor inj uries) times greater than the direct costs [1].

Worldwide, every day more than 12 workers die on the job (more than 4,500 a year), and every year, more than 4.1 million workers suffer a serious work-related injury or illness [1]. Almost 160 million people have work-related diseases; and in one third of these cases, the disease causes a loss of four or more working days [2]. The cost of occupational accidents and diseases in most countries amounts to 2.6 to 3.8 per cent of gross national product [3]. According to the methodology adopted by the United States Occupational Safety \& Health Administration (OSHA), the estimated value of each life lost is $\$ 8.7$ million. If one takes into account the number of deaths at work $(4,547)$ reported by the Bureau of Labour Statistics for the year 2010, the estimated annual cost is almost $\$ 40$ billion [1].

Construction is the second most dangerous work sector in the European Union after the fishing industry, with high annual accident rates and a high number of fatalities. A large number of fatalities in construction in relation to other industry sectors is also reported in the United States, Australia, Japan, Nigeria, and other countries. Workers in road construction zones are exposed to hazards connected to construction equipment and poor working conditions. The main causes of injuries at road construction sites are the following: being struck by equipment or objects, extensive physical strain, slips or falls, and long term exposure to harmful substances. The main causes of fatalities include incidents with mobile construction equipment, traffic incidents with heavy construction machinery, and passenger vehicles entering construction or maintenance zones.

The number and cost of occupational injuries, illnesses, and deaths in the construction industry are unacceptably high. However, many of them can be prevented. The data shows that over the past four decades, since the first legal requirement for the development of legislation on occupational safety and health, the number of injuries and deaths at work has decreased by more than 60 per cent [1]. There have been many efforts to improve safety at road construction sites, resulting in a reduction in incident rates. Some of the results are due to the implementation of regulations and directives (e.g. Directive 92/57 of the European Commission for minimum safety and health requirements at temporary or mobile construction sites). However, this is not enough. It is necessary to improve the occupational safety and health system continually in order to reduce the costs and to increase companies' competitiveness and efficiency.

Research clearly shows that efficient and integrated management of safety and health increases a company's operational excellence and profitability $[4,5]$; reduces the number of injuries, illnesses, and deaths; increases productivity; improves the morale and motivation of employees; develops a culture of safety; affects the image and reputation of the company $[1,6,7]$; increases accountability and strong leadership; requires effective participation of employees; integrates health and safety into business processes; and improves policy development and the implementation of health and safety $[1,8,9]$. 
The effectiveness of an occupational safety system is estimated according to the value of safety performance, and is measured by corresponding indicators and methods of multicriteria decision-making for their ranking, selection, and management [17-22]. There are a number of studies about factors, performance, and indicators of occupational safety $[4,8,10-16]$.

In this study, a systematic approach is applied to the analysis of safety indicators. Factors, performance, and indicators of occupational safety are defined. The expert evaluation method is used to select the key occupational safety indicators, and the fuzzy AHP method is used to rank them. The case study was conducted at the Serbian road construction company called Road Construction Company Niš.

\section{MATERIALS AND METHOD}

\subsection{Safety factors, performance, and indicators}

The concept of occupational safety performance includes a set of indicators that quantitatively or qualitatively describe the specific effects, contributions, and results achieved in the safety system. Indicators measure change in the level of occupational safety over time, as a result of actions taken to reduce relevant risks [11].

Safety performance is traditionally measured after the loss occurred (e.g. accident rate, injury rate, the cost of injury). This means that there must be an accident, or a person has to been injured, for this performance to be measured. The indicators therefore cannot provide the information necessary to avoid future accidents. These performance indicators are referred to as lagging (or outcome) indicators. Contemporary performance measurement involves identifying indicators of conditions and events that precede an undesirable event, and therefore include evaluation potential. They are associated with proactive activities that identify hazards and assess, eliminate, minimise, or control the risk [12]. These performance indicators are called leading indicators.

Lagging indicators are measures of adverse outcomes such as injuries, accidents, accidents avoided, deviations from the permissible limits of the process, release of chemicals, highlevel alarms, improperly performed procedures, failures of components, and lack of equipment [23]. Leading indicators determine the quality of activities that prevent adverse outcomes [15]. These indicators were selected for early warning in order to prevent the occurrence of accidents. They include training, monitoring and inspection, mechanical integrity testing, timely maintenance, use of checklists, regular screening procedures, risk assessment pertaining to the analysis of the level of protection, and consideration of employee and leader conduct. Leading indicators and lagging indicators differ in granularity and focus. Leading indicators are primarily focused on individual or small organisational units. Outcome indicators are of a broader scope: they focus primarily on the whole organisation, and rarely on the individual. These differences have important implications for data collection, analysis, and measurement of leading indicators [12,24].

The main factors that affect the quality of occupational safety are technical, human, organisational, and environmental factors. Research and knowledge of their nature and timing, and the correlation of objective and subjective performance enable analysis of the nature and trends of their influence. This creates a basis for the management of performance factors of occupational safety - i.e. the occupational safety and health $(\mathrm{OH} \& S)$ system.

Based on the literature review and the authors' own research $[1-3,11,15,16,21,23-27]$, the authors propose a structure for factors, performance, and safety indicators (Table 1). This structure is neither complete nor final. New performance indicators and factors can be added for a specific industry by specialiation of the indicators presented. Indicators highlighted with an asterisk $(*)$ in Table 1 are typical for road construction, according to the results of the case study presented in Section 3. The environmental indicators that are 
usually not taken into consideration during the analysis of the $\mathrm{OH} \& S$ system are also included.

Table 1: Factors, performance, and indicators of occupational safety (based on $[1-3,11,15,16,21,23-27])$

\begin{tabular}{|c|c|c|}
\hline Factors & Performance & Indicators \\
\hline 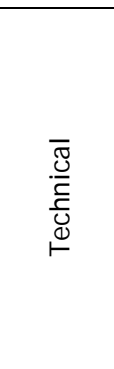 & $\begin{array}{l}\text { Costs } \\
\text { Flexibility } \\
\text { Functionality } \\
\text { Maintenance }\end{array}$ & $\begin{array}{l}\text { T1-Number of safety levels* } \\
\text { T2-Number of controlled deviations of process parameters } \\
\text { T3-Reliability } \\
\text { T4-Availability (readiness to perform functions when necessary) } \\
\text { T5-Number of failures of technical safety systems* } \\
\text { T6-Number of accidents* } \\
\text { T7-Mean time between failures } \\
\text { T8-Mean time between maintenance/ repair } \\
\text { T9-Maintenance rate* } \\
\text { T10-Infrastructure costs } \\
\text { T11-Maintenance costs* }\end{array}$ \\
\hline $\begin{array}{l}\frac{c}{0} \\
\frac{1}{3} \\
\stackrel{1}{I}\end{array}$ & $\begin{array}{l}\text { Competency } \\
\text { Education } \\
\text { Experience } \\
\text { Knowledge } \\
\text { Leadership abilities } \\
\text { Possibility of risk taking } \\
\text { and problem solving } \\
\text { [21] }\end{array}$ & $\begin{array}{l}\text { H1-Application of funds and equipment for personal protection } \\
\text { at work } \\
\text { H2-Rate of occupational injuries* } \\
\text { H3-Index of personnel skills* } \\
\text { H4-Degree of compliance with operating procedures* } \\
\text { H5-Degree of innovativeness of employees } \\
\text { H6-Employee satisfaction index* } \\
\text { H7-Errors and omissions* } \\
\text { H8-Index for result creation using knowledge } \\
\text { H9-Index of communication and reporting skills } \\
\text { H10-Index of probability of success } \\
\text { H11-Investment/ profit ratio for the human factor } \\
\text { H12-Level of effectiveness of training programs } \\
\text { H13-Level of teamwork of employees } \\
\text { H14-Percentage of employees having proper skills development } \\
\text { training } \\
\text { H15-Rate of absenteeism }\end{array}$ \\
\hline 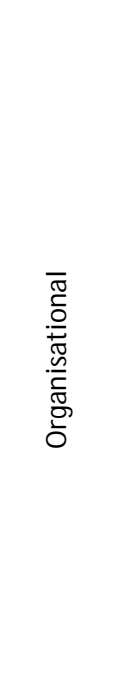 & $\begin{array}{l}\text { Coordination } \\
\text { Design } \\
\text { J ob safety analysis } \\
\text { Management (control) } \\
\text { Planning } \\
\text { Preventive maintenance } \\
\text { programme } \\
\text { Procedures, instructions } \\
\text { Training }\end{array}$ & $\begin{array}{l}\text { O1-Percentage of employees trained in occupational health } \\
\text { and safety }(\mathrm{OH} \& \mathrm{~S}) \\
\text { O2-Efficiency of safety resource management* } \\
\text { O3-Share of jobs with higher risk* } \\
\text { O4-Mean number of years of experience of employees } \\
\text { O5-Share of the processes that have a formal training system } \\
\text { O6-Number of workplace safety controls in practice* } \\
\text { O7-Annual average number of hours of employee training* } \\
\text { O8-Number of guidelines for OH\&S of employees* } \\
\text { O9-Expenses for injuries at work } \\
\text { O10-Evidence of the measures applied to protect assets and } \\
\text { equipment for work } \\
\text { O11-Number of cases of illness due to stress of employees in } \\
\text { the workplace } \\
\text { O12-Number of cases of mobbing in the workplace } \\
\text { O13-Number of hours of accident inspections } \\
\text { O15-Number of negative findings on performed technical } \\
\text { inspection and examination of the work equipment, tools and } \\
\text { equipment for personal safety, and working environment } \\
\text { conditions } \\
\text { O16-Number of persons trained in first aid }\end{array}$ \\
\hline
\end{tabular}




\begin{tabular}{|c|c|c|}
\hline Factors & Performance & Indicators \\
\hline 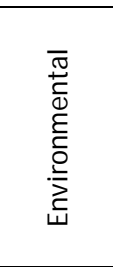 & $\begin{array}{l}\text { Competitive } \\
\text { environment } \\
\text { Legislation } \\
\text { Perceptions and values } \\
\text { of stakeholders } \\
\text { Protection technology } \\
\text { Social environment } \\
\text { Standardisation }\end{array}$ & $\begin{array}{l}\text { E1-Level of safety technologies* } \\
\text { E2-Level of legislation implementation* } \\
\text { E3-Number of implemented voluntary standards* } \\
\text { E4-Degree of networking in companies } \\
\text { E5-Number of available databases on accidents* } \\
\text { E6-Amount of available funds* }\end{array}$ \\
\hline
\end{tabular}

\subsection{Fuzzy AHP-based ranking of occupational safety indicators}

The quality of occupational safety systems is a function of many factors. Management of those systems, therefore, requires an holistic approach and a multi-criteria analysis $[5,25]$. The analytic hierarchy process (AHP) is used to tackle multi-criteria decision-making problems and to determine priorities in occupational safety systems [17-20,22].

The original AHP was developed by Thomas L. Saaty [28]. It is a multi-criteria decisionmaking methodology that considers both subjective and objective factors in the evaluation process. In the original AHP method, human judgments are represented as crisp values. However, in many practical cases the human preference model is uncertain, and decisionmakers cannot assign crisp values to comparison judgments. The use of fuzzy set theory allows decision-makers to incorporate unquantifiable information, incomplete information, unobtainable information, and partially-unknown facts into the decision model [22]. The fuzzy AHP method is an extension of the crisp AHP method [29], in which human judgments are represented as fuzzy values. Using fuzzy numbers to evaluate occupational safety factors and indicators helps to represent the actual safety problem more realistically.

The mathematical basis for the fuzzy AHP method consists of matrix theory and fuzzy arithmetic. In this paper we use triangular fuzzy numbers. A fuzzy number is a special fuzzy set $F=\left\{\left(x, \mu_{F}(x)\right), x \in R\right\}$, where $x \in(-\infty,+\infty)$, and $\mu_{F}(x):(-\infty,+\infty) \rightarrow[0,1]$ is a continuous function. A triangular fuzzy number can be denoted as $M=(l, m, u)$, and the membership function is:

$$
\mu_{F}(x)=\left\{\begin{array}{c}
\frac{x-l}{m-l}, x \in[l, m] \\
\frac{u-x}{u-m}, x \in[m, u] \\
0, \quad \text { otherwise }
\end{array}\right.
$$

where $l \leq m \leq u, l$ and $u$ stand for the lower and upper value of the support of $M$ respectively, and $m$ is the modal value. When $l=m=u$, it is a 'normal' crisp number.

The main laws for operations for two triangular fuzzy numbers $M_{1}$ and $M_{2}$ are:

$$
\begin{aligned}
& M_{1} \oplus M_{2}=\left(l_{1}, m_{1}, u_{1}\right) \oplus\left(l_{2}, m_{2}, u_{2}\right)=\left(l_{1}+l_{2}, m_{1}+m_{2}, u_{1}+u_{2}\right) \\
& \lambda \cdot M_{1}=\lambda \cdot\left(l_{1}, m_{1}, u_{1}\right)=\left(\lambda \cdot l_{1}, \lambda \cdot m_{1}, \lambda \cdot u_{1}\right), \forall \lambda>0 \\
& M_{1} \otimes M_{2}=\left(l_{1}, m_{1}, u_{1}\right) \otimes\left(l_{2}, m_{2}, u_{2}\right)=\left(l_{1} \cdot l_{2}, m_{1} \cdot m_{2}, u_{1} \cdot u_{2}\right), l_{1}, l_{2}>0 \\
& M_{1}^{-1}=\left(l_{1}, m_{1}, u_{1}\right)^{-1}=\left(\frac{1}{u_{1}}, \frac{1}{m_{1}}, \frac{1}{l_{1}}\right)
\end{aligned}
$$

The value of the fuzzy synthetic extent, according to Chang's extent analysis method [30], is defined as: 


$$
S_{i}=\sum_{j=1}^{m} M_{g_{i}}^{j} \otimes\left[\sum_{i=1}^{n} \sum_{j=1}^{m} M_{g_{i}}^{j}\right]^{-1}, i=1,2, \ldots, n
$$

where $M_{g_{i}}^{j}$ is a triangular fuzzy number representing the extent analysis value for decision element $\mathrm{i}$ with respect to goal $\mathrm{j}$, and $\otimes$ is the fuzzy multiplication operator.

Fuzzy AHP involves the following steps: 1 . the overall goal (objective) is identified and clearly defined; 2 . the criteria, sub-criteria, and alternatives that contribute to the overall goal are identified; 3 . the hierarchical structure is formed; 4 . pairwise comparison is made using a fuzzified Saaty's evaluation scale; 5 . the priority weighting vectors are evaluated using the eigenvalue method, the fuzzy extent analysis, and the aggregation principle; and 6 . the defuzzification and the final ranking of alternatives is conducted.

The fuzzy AHP method is applied to the ranking of occupational safety indicators, as presented below.

Goal identification. The goal is to rank key occupational safety indicators.

Identification of criteria, sub-criteria, and alternatives. Basic requirements on which occupational safety is based (risk, costs, and social responsibility) are identified as criteria; factors affecting the quality of occupational safety (technical, human, organisational, and external environmental factors) as sub-criteria; and the key occupational safety indicators are identified as alternatives.

Key performance indicators of occupational safety are determined by experts' assessments using the list of indicators shown in Table 1.

To examine the degree of agreement between the experts, the ranking is done based on indicators in the priority list of each expert. The highest rank (rank 1) goes to the indicator that, in the opinion of the experts, is the most significant, and the lowest rank (rank n) to the least significant indicator. If some indicators are equally important, the same ranks are assigned to them. Ranking that does not include the same ranks defines strict ranking (total order); otherwise it is free ranking (weak order). During ranking of the indicators, the sum of ranks assigned to the elements should be equal to the sum of a series of integers from 1 to $n$, where $n$ is the number of ranked elements. To meet this requirement, even when the ranking is free, standardised ranks are applied. They are determined as the arithmetic mean of the ordinal numbers of elements in the ranked series of the same rank.

The degree of agreement between the experts' opinions is defined by the coefficient of concordance. The coefficient of concordance for strict ranking is calculated as follows [31]:

$$
W=S / S_{m}
$$

where $S=\sum_{j=1}^{n}\left(\sum_{i=1}^{m} r_{i j}-m(n+1) / 2\right)^{2} ; S_{m}=m^{2} n\left(n^{2}-1\right) / 12 ; n$ - the number of indicators; $\mathrm{m}$ - the number of experts; and $r_{i j}$ - the rank of the $\mathrm{j}$-th indicator assigned by the i-th expert.

The coefficient of concordance for weak ranking is calculated as follows [31]:

$$
W=S / S_{m}^{\prime}
$$


where $S_{m}^{\prime}=\frac{m^{2}}{12} n\left(n^{2}-1\right)-\frac{m}{12} \sum_{i=1}^{m} \sum_{k=1}^{L_{k}}\left(l_{k}^{3}-l_{k}\right) ; l_{k}$ - the number of equal ranks in the $\mathrm{k}$ th group of the $\mathrm{i}$-th expert ranking; $L_{k}$ - the number of groups of equal ranks in the $\mathrm{i}$-th expert ranking; and $\mathrm{S}, \mathrm{m}$, and $\mathrm{n}$ have the same meaning as in Eq. 7 for strict ranking.

Concordance coefficient values vary over the range from 0 to 1 . Value 1 indicates full compliance with the experts' opinions, and the value of 0 their complete disagreement. If $W>0.5$, it is taken that the approval of an expert's opinion and all the lists of priorities are considered relevant. If $W \leq 0.5$, it is taken that there is insufficient agreement among the opinions of the experts. In that case, by excluding the expert opinions one by one, the concordance coefficient is recalculated. The opinion of the experts whose exclusion reduces the coefficient of concordance is adopted, whereas the opinions of those experts whose exclusion increases the coefficient of concordance are ignored. Furthermore, the newly formed group of experts determines the concordance coefficient one more time, and if $W>0.5$, the opinions of these experts are considered to be relevant. Otherwise, the procedure is repeated with a new group of experts. After confirmation of compliance among the experts' opinions, and by assuming that all the experts are equally competent, key performance indicators are determined, based on the mean rank for each indicator.

Hierarchical structure formation. The fuzzy AHP method presents a problem in the form of hierarchy. Generally, a hierarchy is structured from the top level (goal or objective), through intermediate levels (criteria and sub-criteria), to the lowest level (alternatives). To rank key occupational safety indicators, it is important to define the hierarchical structure, which has four levels: the first (or top) level represents the ranking of key occupational safety indicators; the second level considers relevant criteria (risk, costs, and social responsibility); the third level considers relevant sub-criteria (technical, human, organisational, and environmental factors); and the fourth level defines key occupational safety indicators. Figure 1 shows the hierarchical scheme for ranking occupational safety indicators.

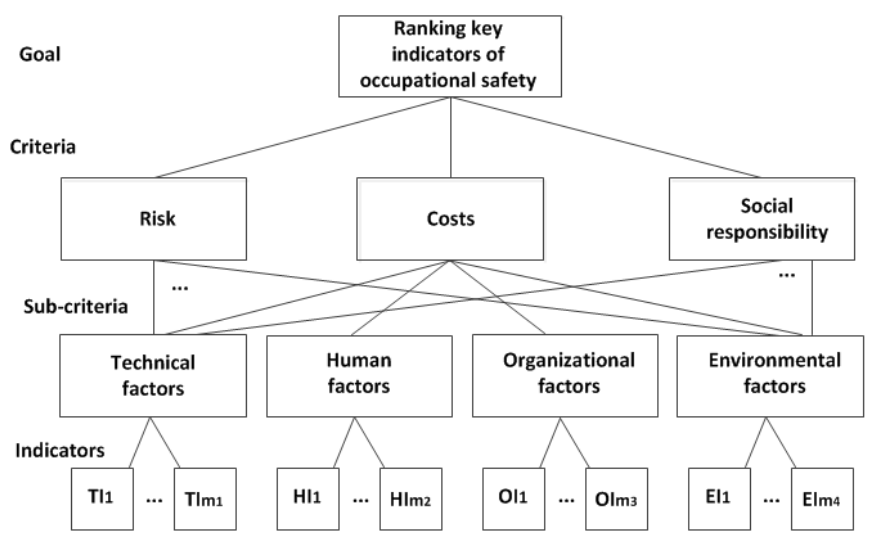

Figure 1: Hierarchy scheme for ranking occupational safety indicators

Pairwise comparison. Pairs of elements at each level are compared according to their relative contribution to the elements at the hierarchical level above theirs. The decisionmaker or expert group estimates the relative contribution of each pair using the 1-9 comparison scale, as shown in Table 2. The fuzzified scale for pairwise comparisons is defined by means of fuzzy distance $\delta$, which has values $0.5 \leq \delta \leq 2$.

In this paper fuzzification is implemented by triangular fuzzy numbers, and the value of fuzzy distance of 2 is used; on boundaries, $(1,1,3)$ is used for 1 and $(7,9,9)$ is used for 9. 
A fuzzy distance of 2 is used for odds $(3,5,7)$, and a fuzzy distance of 1 for pairs $(2,4,6$, 8) as recommended in [29], where the most consistent results were obtained.

Table 2: Crisp and fuzzified Saaty's scale for pairwise comparisons [29]

\begin{tabular}{lll}
\hline Crisp values (x) & Judgment description & Fuzzy values \\
\hline 1 & Equal importance & $(1,1,1+\delta)$ \\
3 & Weak dominance & $(3-\delta, 3,3+\delta)$ \\
5 & Strong dominance & $(5-\delta, 5,5+\delta)$ \\
7 & Demonstrated dominance & $(7-\delta, 7,7+\delta)$ \\
9 & Absolute dominance & $(9-\delta, 9,9)$ \\
$2,4,6,8$ & Intermediate values & $(x-1, x, x+1)$ \\
\hline
\end{tabular}

Pairwise comparisons at each level, starting from the top of the hierarchy, are presented in the square matrix form $A=\left[\tilde{a}_{i j}\right\rfloor_{i, j=\overline{1, n}}$, where $\tilde{a}_{i j}$ is the fuzzy value about the relative importance of alternative $\mathrm{i}$ over alternative $\mathrm{j}, \widetilde{a}_{i j}=1$ for $\mathrm{i}=\mathrm{j}$ and $\tilde{a}_{i j}=1 / \widetilde{a}_{j i}$ for $i \neq j$.

Priority weight vectors evaluation. The ranking procedure starts with the determination of the criteria weight vector:

$W_{c}=\left(w_{c 1}, w_{c 2}, w_{c 3}\right)=\left(w_{R}, w_{C}, w_{S R}\right)$

The corresponding weights of criteria, with respect to Eq. 6, are determined as:

$w_{c i}=\sum_{j=1}^{3} \tilde{a}_{i j} \otimes\left[\sum_{i=1}^{3} \sum_{j=1}^{3} \tilde{a}_{i j}\right]^{-1}, i=1,2,3$

Sub-criteria weight vectors are defined by pairwise comparison of sub-criteria according to every single criterion. The corresponding elements of this vector, according to Eq. 6, are calculated as follows:

$x_{i j}=\sum_{j=1}^{3} \tilde{a}_{i j} \otimes\left[\sum_{l=1}^{4} \sum_{j=1}^{3} \tilde{a}_{l j}\right]^{-1}$

where $x_{i j}$ represents the resultant fuzzy performance assessment of the i-th sub-criterion with respect to the $j$-th criterion. The final sub-criteria weights are derived through the aggregation of the weights at two consecutive levels, i.e. through multiplying sub-criteria weights by criteria weights:

$W_{s c}=X \otimes W_{c}=\left(w_{s c 1}, w_{s c 2}, w_{s c 3}, w_{s c 4}\right)=\left(w_{T F}, w_{H F}, w_{O F}, w_{E F}\right)$

Finally, the alternatives (key indicators of occupational safety) are compared according to the relevant sub-criterion. Corresponding weights of alternatives for individual sub-criteria are determined according to Eq. 6, and the final weight is obtained by multiplying the weight of the alternatives and the final weight of the corresponding sub-criterion:

$w_{k}^{p}=\left(\sum_{j=1}^{m_{k}} \tilde{a}_{i j} \otimes\left[\sum_{i=1}^{m_{k}} \sum_{j=1}^{m_{k}} \tilde{a}_{i j}\right]^{-1}\right) \otimes w_{s c k}, k=1, \ldots, 4, p=1, \ldots, m_{k}$

where $w_{k}^{p}$ are the aggregated fuzzy weights of the $\mathrm{p}$-th alternative with respect to the $\mathrm{k}$-th sub-criterion, and the elements of the alternative weight vector are:

$W_{a}=\left(w_{1}{ }^{1}, \ldots, w_{1}^{m_{1}}, w_{2}{ }^{1}, \ldots, w_{2}{ }^{m_{2}}, w_{3}{ }^{1}, \ldots, w_{3}{ }^{m_{3}}, w_{4}{ }^{1}, \ldots, w_{4}{ }^{m_{4}}\right)$

Defuzzification and the final ranking of alternatives. Triangular fuzzy numbers are ranked by applying several methods, such as the centre of gravity method, the dominance measure method, the a-cut with interval synthesis method, and the total integral value method. The total integral value method, presented in [32], is used in this paper. For the given triangular fuzzy number $M=(I, m, u)$, the total integral value is defined as follows: 


$$
I_{T}^{\lambda}(M)=0.5(\lambda u+m+(1-\lambda) l), \lambda \in[0,1]
$$

where $\lambda$ represents an optimism index. It describes the decision maker's attitude toward risk: the smaller value of $\lambda$ indicates a higher degree of risk (a lower degree of optimism). Values 0 , 0.5 , and 1 are used to represent the pessimistic, moderate, and optimistic views of the decisionmaker respectively. If $I_{T}^{\lambda}\left(M_{1}\right)<I_{T}^{\lambda}\left(M_{2}\right)$, then $M_{1} \prec M_{2}$; if $I_{T}^{\lambda}\left(M_{1}\right)=I_{T}^{\lambda}\left(M_{2}\right)$, then $M_{1} \approx M_{2}$; if $I_{T}^{\lambda}\left(M_{1}\right)>I_{T}^{\lambda}\left(M_{2}\right)$, then $M_{1} \succ M_{2}$. This method is used for the ranking of alternatives according to the moderate and optimistic attitudes toward risk.

\section{CASE STUDY}

The described method of ranking safety indicators will be used in the example of the Road Construction Company Niš. This company has a long and successful tradition in its field, and is currently the leader in the domestic travel industry, as evidenced by the number of newly-constructed sections of roads in Serbia. The road construction company Niš maintains $1,366.2 \mathrm{~km}$ of roads. This is the basic network of roads in the Niš, Pirot, and Toplica districts that provide a smooth flow for 90 per cent of road traffic in the territory. Longterm plans are that the company, as part of the Nibens Group, contributes to its strengthening and increases competitiveness in both the domestic and the foreign markets. The activity of the company includes construction and maintenance of highways and roads; construction and maintenance of city roads; construction of airport runways; construction and maintenance of bridges; construction and maintenance of tunnels; and production of stone materials.

During our research into safety indicators in this company, we began with the basic requirements on which occupational safety is based (risk (R), costs (C), and social responsibility (SR)); factors that influence the quality of occupational safety (technical (TF), human (HF), organisational (OF), and environmental factors (EF)); and an extensive list of indicators that are classified according to key factors (Table 1). To determine the key occupational safety indicators, this list was presented to the risk assessors (experts) at the Institute for Quality of Working and Living Environment '1. Maj' in Niš. These experts participated in the risk assessment necessary for the preparation of the document on risk assessment for a number of road construction companies, including the road construction company Niš. Although they had the option of adding new indicators, the experts did not do so, arguing that the key indicators were already on the proposed list. Among the 48 indicators on the list, the experts selected 20 key indicators (five indicators within each group of factors) that best represent the state of occupational safety in road construction companies. Ranking results and the corresponding coefficients of concordance are shown in Tables 3 to 6.

Table 3: Expert ranking of technical indicators

\begin{tabular}{cccccccccccc}
\hline & T1 & T2 & T3 & T4 & T5 & T6 & T7 & T8 & T9 & T10 & T11 \\
\hline Expert1 & 1 & 7 & 6 & 10 & 3 & 2 & 9 & 8 & 4 & 11 & 5 \\
Expert2 & 1 & 9 & 6 & 10 & 3 & 2 & 7 & 8 & 5 & 11 & 5 \\
Expert3 & 1 & 7 & 5 & 11 & 2 & 3 & 9 & 8 & 4 & 10 & 6 \\
Expert4 & 1 & 7 & 6 & 11 & 3 & 2 & 8 & 9 & 4 & 10 & 5 \\
Expert5 & 1 & 8 & 5 & 10 & 2 & 3 & 7 & 9 & 6 & 11 & 4 \\
\hline \multicolumn{11}{c}{ Coefficient of concordance: $W=0.8316$} \\
\hline
\end{tabular}

The most important technical indicators are: T1 - the number of safety levels (TI1); T5 - the number of failures of technical safety systems (TI2); T6 - the number of accidents (TI3); T9 - maintenance rate (TI4); and T11 - maintenance costs (TI5).

The most important human indicators are: $\mathrm{H} 2$ - the rate of occupational injuries (HI); H3 an index of personal skills (HI2); $\mathrm{H} 4$ - the degree of compliance with operating procedures (HI3); $\mathrm{H} 6$ - employee satisfaction index (HI4); and $\mathrm{H} 7$ - the number of errors and omissions (HI5). 
Table 4: Expert ranking of human indicators

\begin{tabular}{cccccccccccccccc}
\hline & $\mathrm{H} 1$ & $\mathrm{H} 2$ & $\mathrm{H} 3$ & $\mathrm{H} 4$ & $\mathrm{H} 5$ & $\mathrm{H} 6$ & $\mathrm{H} 7$ & $\mathrm{H} 8$ & $\mathrm{H} 9$ & $\mathrm{H} 10$ & $\mathrm{H} 11$ & $\mathrm{H} 12$ & $\mathrm{H} 13$ & $\mathrm{H} 14$ & $\mathrm{H} 15$ \\
\hline Expert1 & 6 & 3 & 2 & 1 & 15 & 5 & 4 & 7 & 8 & 13 & 14 & 11 & 12 & 9 & 10 \\
Expert2 & 5 & 4 & 2 & 1 & 15 & 3 & 6 & 7 & 10 & 11 & 13 & 12 & 14 & 8 & 9 \\
Expert3 & 7 & 5 & 3 & 1 & 15 & 2 & 4 & 6 & 11 & 8 & 14 & 13 & 12 & 9 & 10 \\
Expert4 & 6 & 3 & 1 & 2 & 12 & 5 & 4 & 7 & 8 & 9 & 14 & 15 & 13 & 11 & 10 \\
Expert5 & 7 & 3 & 2 & 1 & 15 & 4 & 5 & 6 & 9 & 8 & 13 & 12 & 14 & 10 & 11 \\
\hline \multicolumn{18}{c}{ Coefficient of concordance: } & W=0.7287 \\
\hline
\end{tabular}

Table 5: Expert ranking of organisational indicators

\begin{tabular}{ccccccccccccccccc}
\hline & 01 & 02 & 03 & 04 & 05 & 06 & 07 & 08 & 09 & 010 & 011 & 012 & 013 & 014 & 015 & 016 \\
\hline Expert1 & 6 & 1 & 3 & 10 & 8 & 2 & 4 & 5 & 13 & 11 & 14 & 15 & 12 & 7 & 9 & 13 \\
Expert2 & 6 & 2 & 4 & 10 & 7 & 1 & 3 & 5 & 14 & 12 & 13 & 16 & 11 & 8 & 9 & 15 \\
Expert3 & 7 & 1 & 3 & 10 & 6 & 2 & 5 & 4 & 16 & 11 & 14 & 15 & 13 & 9 & 8 & 12 \\
Expert4 & 6 & 3 & 1 & 10 & 8 & 2 & 4 & 5 & 13 & 12 & 11 & 16 & 14 & 7 & 9 & 15 \\
Expert5 & 6 & 1 & 5 & 10 & 9 & 2 & 4 & 3 & 15 & 14 & 13 & 16 & 12 & 8 & 7 & 11 \\
\hline
\end{tabular}

The most important organisational indicators are: 02 - the efficiency of safety resource management (OI1); 03 - the share of jobs with higher risk (0I2); 06 - the number of workplace safety controls in practice (OI3); 07 - the annual average number of hours of employee training (OI4); and 08 - the number of $\mathrm{OH} \& \mathrm{~S}$ guidelines for employees (OI5).

Table 6: Expert ranking of environmental indicators

\begin{tabular}{lcccccc}
\hline & E1 & E2 & E3 & E4 & E5 & E6 \\
\hline Expert1 & 1 & 2 & 3 & 6 & 4 & 5 \\
Expert2 & 1 & 2 & 3 & 6 & 4 & 5 \\
Expert3 & 1 & 2 & 3 & 6 & 4 & 5 \\
Expert4 & 1 & 2 & 3 & 6 & 4 & 5 \\
Expert5 & 1 & 2 & 3 & 6 & 4 & 5 \\
\hline \multicolumn{2}{c}{ Coefficient of concordance: $W=1$}
\end{tabular}

The most important environmental indicators are: E1 - the level of safety technologies (EI1); E2 - the level of legislation implementation (EI2); E3 - the number of implemented voluntary standards (EI3); E5 - the number of available databases on accidents (EI4); and E6 - the amount of available funds (EI5).

After establishing the key indicators, the experts at the joint session made the following comparisons: comparison of the criteria, comparison of the sub-criteria according to each criterion individually, and comparison of key indicators within each sub-criterion. The results of the comparisons are shown in Tables 7-14.

Table 7: Pairwise comparison of safety criteria

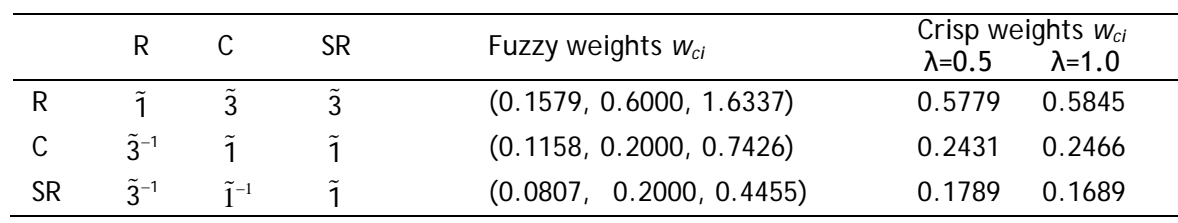

Table 8: Pairwise comparison of sub-criteria in relation to the risk

\begin{tabular}{ccccccccc}
\hline & TF & HF & OF & EF & Fuzzy weights $x_{i 1}$ & \multicolumn{2}{c}{ Crisp weights $x_{i 1}$} \\
& & & & & 0.5 & $\lambda=1.0$ \\
\hline TF & $\tilde{1}$ & $\tilde{3}^{-1}$ & $\tilde{3}^{-1}$ & $\tilde{3}$ & $(0.0590,0.1768,0.5257)$ & 0.1750 & 0.1762 \\
HF & $\tilde{3}$ & $\tilde{1}$ & $\tilde{1}$ & $\tilde{5}$ & $(0.1475,0.3788,1.0513)$ & 0.3924 & 0.3957 \\
OF & $\tilde{3}$ & $\tilde{1}^{-1}$ & $\tilde{1}$ & $\tilde{5}$ & $(0.1311,0.3788,0.9199)$ & 0.3618 & 0.3586 \\
EF & $\tilde{3}^{-1}$ & $\tilde{5}^{-1}$ & $\tilde{5}^{-1}$ & $\tilde{1}$ & $(0.0365,0.0657,0.1752)$ & 0.0708 & 0.0696 \\
\hline
\end{tabular}


Table 9: Pairwise comparison of sub-criteria in relation to the costs

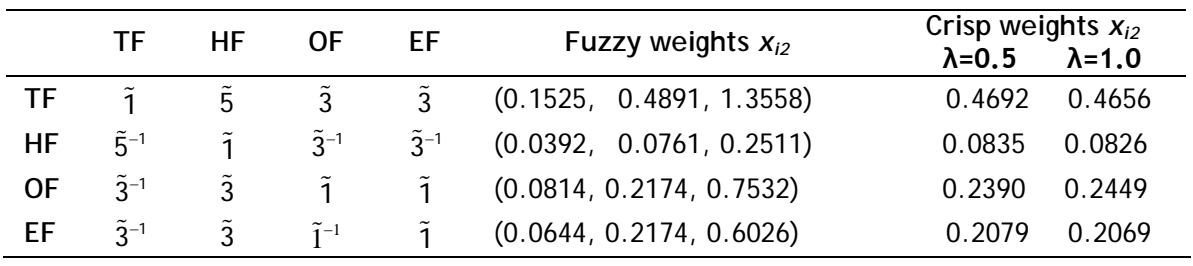

Table 10: Pairwise comparison of sub-criteria in relation to social responsibility

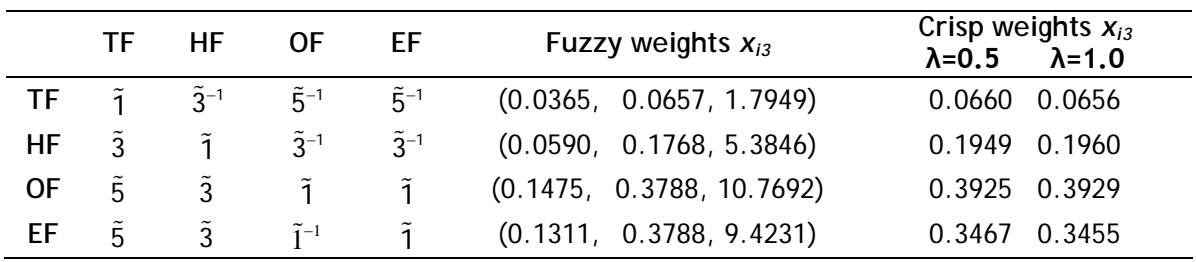

Table 11: Pairwise comparison of key technical indicators

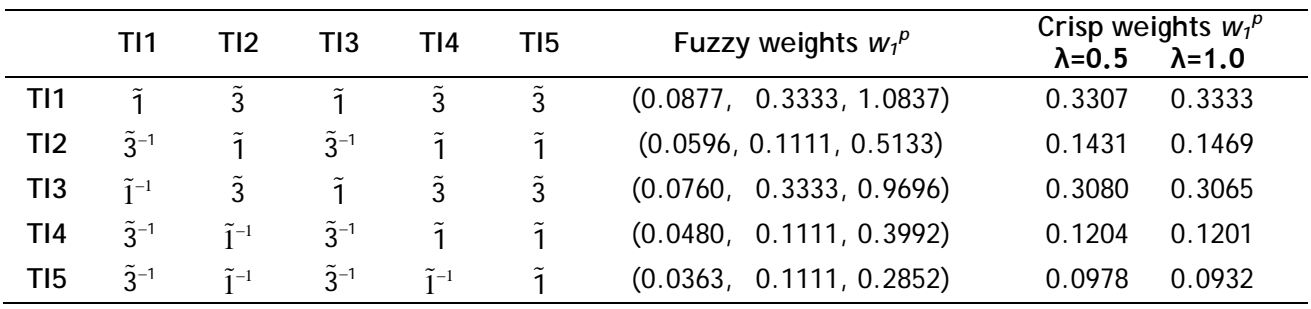

Table 12: Pairwise comparison of key human indicators

\begin{tabular}{|c|c|c|c|c|c|c|c|c|}
\hline & HII & HI2 & HI3 & HI4 & HI5 & Fuzzy weights $w_{2}{ }^{p}$ & \multicolumn{2}{|c|}{ Crisp weights $w_{2}{ }^{p}$} \\
\hline HI1 & $\tilde{1}$ & $\tilde{1}$ & $\tilde{3}^{-1}$ & $\tilde{3}$ & $\tilde{1}$ & $(0.0737,0.1919,0.7414)$ & 0.2157 & 0.2196 \\
\hline HI2 & $\tilde{1}^{-1}$ & $\tilde{1}$ & $\tilde{1}$ & $\tilde{3}$ & $\tilde{1}$ & $(0.0760,0.2121,0.7414)$ & 0.2234 & 0.2243 \\
\hline HI3 & $\tilde{3}$ & $\tilde{1}^{-1}$ & $\tilde{1}$ & $\tilde{3}$ & $\tilde{3}$ & $(0.0760,0.3333,0.9696)$ & 0.3080 & 0.3065 \\
\hline HI4 & $\tilde{3}^{-1}$ & $\tilde{3}^{-1}$ & $\tilde{3}^{-1}$ & $\tilde{1}$ & $\tilde{3}^{-1}$ & $(0.0316,0.0707,0.2852)$ & 0.0824 & 0.0837 \\
\hline HI5 & $\tilde{1}^{-1}$ & $\tilde{1}^{-1}$ & $\tilde{3}^{-1}$ & $\tilde{3}$ & $\tilde{1}$ & $(0.0503,0.1919,0.5133)$ & 0.1704 & 0.1659 \\
\hline
\end{tabular}

Table 13: Pairwise comparison of key organisational indicators

\begin{tabular}{|c|c|c|c|c|c|c|c|c|}
\hline & Ol1 & 012 & 013 & 014 & 015 & Fuzzy weights $w_{3}{ }^{p}$ & Crisp w & ghts $w_{3}$ \\
\hline Ol1 & $\tilde{1}$ & $\tilde{3}$ & $\tilde{1}$ & $\tilde{3}$ & $\tilde{3}$ & $03333 \quad 10837)$ & 03307 & 03333 \\
\hline & & & & & & & & \\
\hline 012 & $\tilde{3}^{-1}$ & $\tilde{1}$ & $\tilde{3}^{-1}$ & $\tilde{1}$ & $\tilde{1}$ & $0.1111,0.5133)$ & 0.1431 & 0.1469 \\
\hline 013 & $\tilde{1}^{-1}$ & $\tilde{3}$ & $\tilde{1}$ & $\tilde{3}$ & $\tilde{3}$ & $(0.0760,0.3333,0.9696)$ & 0.3080 & 0.3065 \\
\hline 014 & $\tilde{3}^{-1}$ & $\tilde{1}^{-1}$ & $\tilde{3}^{-1}$ & $\tilde{1}$ & $\tilde{1}$ & $(0.0480,0.1111,0.3992)$ & 0.1204 & 0.1201 \\
\hline 015 & $\tilde{3}^{-1}$ & $\tilde{1}^{-1}$ & $\tilde{3}^{-1}$ & $\tilde{1}^{-1}$ & $\tilde{1}$ & $(0.0363,0.1111,0.2852)$ & 0.0978 & 0.0932 \\
\hline
\end{tabular}

Table 14: Pairwise comparison of key environmental indicators

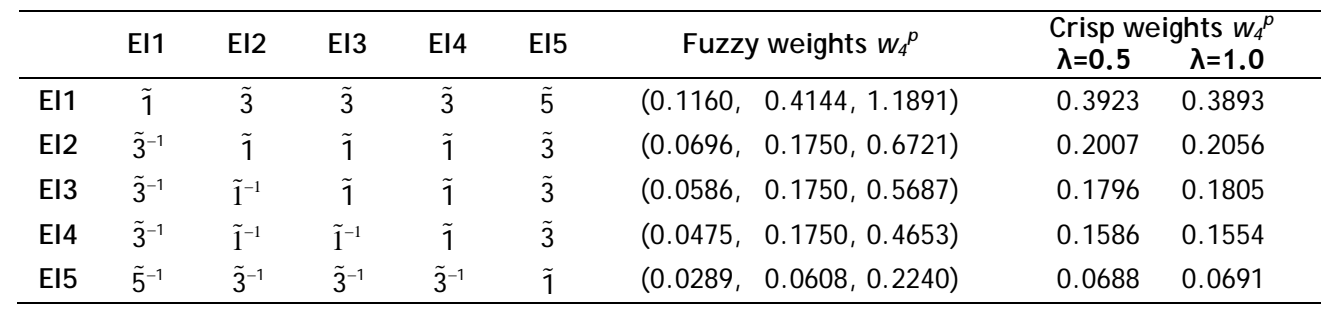


According to the data presented, and with respect to equations 12 and 13 , the following results were obtained:

\section{Final priorities of sub-criteria}

$$
W_{s c}=X \otimes W_{c}=\left[\begin{array}{c}
(0.0299,0.2170,2.6652) \\
(0.0326,0.2778,4.3030) \\
(0.0420,0.3465,6.8603) \\
(0.0238,0.1586,4.9321)
\end{array}\right]=\left[\begin{array}{c}
w_{T F} \\
w_{H F} \\
w_{O F} \\
w_{E F}
\end{array}\right]
$$

\section{Final priorities of key occupational safety indicators}

$$
\begin{aligned}
& {\left[w_{1}{ }^{p}\right]\left[w_{T F}\right]=\left[\begin{array}{c}
(0.0026,0.0723,2.8882) \\
(0.0018,0.0241,1.3681) \\
(0.0023,0.0723,2.5842) \\
(0.0014,0.0241,1.0641) \\
(0.0011,0.0241,0.7600)
\end{array}\right]=\left[\begin{array}{l}
w_{T I 1} \\
w_{T I 2} \\
w_{T I 3} \\
w_{T I 4} \\
w_{T I 5}
\end{array}\right]} \\
& {\left[w_{1}{ }^{p}\right]\left[w_{T F}\right]=\left[\begin{array}{c}
(0.0026,0.0723,2.8882) \\
(0.0018,0.0241,1.3681) \\
(0.0023,0.0723,2.5842) \\
(0.0014,0.0241,1.0641) \\
(0.0011,0.0241,0.7600)
\end{array}\right]=\left[\begin{array}{l}
w_{T I 1} \\
w_{T I 2} \\
w_{T I 3} \\
w_{T I 4} \\
w_{T I 5}
\end{array}\right]} \\
& {\left[w_{3}{ }^{P}\right]\left[w_{O F}\right]=\left[\begin{array}{l}
(0.0037,0.1155,7.4342) \\
(0.0025,0.0385,3.5215) \\
(0.0032,0.1155,6.6516) \\
(0.0020,0.0385,2.7389) \\
(0.0015,0.0385,1.9564)
\end{array}\right]=\left[\begin{array}{l}
w_{O I 1} \\
w_{O I 2} \\
w_{O I 3} \\
w_{O I 4} \\
w_{O I 5}
\end{array}\right]} \\
& {\left[w_{4}{ }^{P}\right]\left[w_{E F}\right]=\left[\begin{array}{l}
(0.0028,0.0657,5.8646) \\
(0.0017,0.0278,3.3148) \\
(0.0014,0.0278,2.8048) \\
(0.0011,0.0278,2.2949) \\
(0.0007,0.0096,1.1049)
\end{array}\right]=\left[\begin{array}{l}
w_{E I 1} \\
w_{E I 2} \\
w_{E I 3} \\
w_{E I 4} \\
w_{E I 5}
\end{array}\right]}
\end{aligned}
$$

After the defuzzification of the final weights of factors and alternatives according to Eq. 15, factors and key performance indicators of occupational safety were ranked. Ranking results are shown in Tables 15 and 16.

Table 15: Final weights (FWs) for safety factors

\begin{tabular}{lcccc}
\hline Safety factors & \multicolumn{2}{c}{$\lambda=\mathbf{0 . 5}$} & \multicolumn{2}{c}{$\lambda=\mathbf{1 . 0}$} \\
& FWs & No & FWs & No \\
\hline Technical factors & 0.1498 & 4 & 0.1459 & 4 \\
Human factors & 0.2342 & 3 & 0.2318 & 3 \\
Organisational factors & 0.3636 & 1 & 0.3647 & 1 \\
Environmental factors & 0.2524 & 2 & 0.2576 & 2 \\
\hline
\end{tabular}


Table 16: Final weights (FWs) for safety indicators

\begin{tabular}{|c|c|c|c|c|c|}
\hline \multirow{2}{*}{ Factors } & \multirow{2}{*}{ Safety indicators } & \multicolumn{2}{|c|}{$\lambda=0.5$} & \multicolumn{2}{|c|}{$\lambda=1.0$} \\
\hline & & FWs & No & FWs & No \\
\hline \multirow{5}{*}{$\begin{array}{l}\text { Technical } \\
\text { factors (TF) }\end{array}$} & The number of safety levels (TI1) & 0.0487 & 9 & 0.0483 & 9 \\
\hline & $\begin{array}{l}\text { The number of failures of technical safety systems } \\
\text { (TI2) }\end{array}$ & 0.0227 & 16 & 0.0227 & 16 \\
\hline & The number of accidents $(T \mid 3)$ & 0.0438 & 12 & 0.0433 & 12 \\
\hline & The intensity of maintenance (TI4) & 0.0179 & 19 & 0.0177 & 19 \\
\hline & Maintenance costs (TI5) & 0.0130 & 20 & 0.0128 & 20 \\
\hline \multirow{5}{*}{$\begin{array}{l}\text { Human factors } \\
\text { (HF) }\end{array}$} & The rate of injuries (HI1) & 0.0529 & 8 & 0.0529 & 8 \\
\hline & An index of skills of employees (HI2) & 0.0531 & 7 & 0.0530 & 7 \\
\hline & $\begin{array}{l}\text { The degree of compliance with operating } \\
\text { procedures }(\mathrm{HI} 3)\end{array}$ & 0.0699 & 4 & 0.0695 & 4 \\
\hline & Employee satisfaction index (HI4) & 0.0203 & 17 & 0.0203 & 17 \\
\hline & The number of errors and omissions (HI5) & 0.0371 & 14 & 0.0369 & 14 \\
\hline \multirow{5}{*}{$\begin{array}{l}\text { Organisational } \\
\text { factors (OF) }\end{array}$} & The efficiency of safety resource management (OI1) & 0.1229 & 1 & 0.1231 & 1 \\
\hline & The share of jobs with higher risk (OI2) & 0.0577 & 5 & 0.0580 & 5 \\
\hline & $\begin{array}{l}\text { The number of controls of workplace safety in } \\
\text { practice }(\mathrm{O} / 3)\end{array}$ & 0.1104 & 2 & 0.1103 & 2 \\
\hline & $\begin{array}{l}\text { The annual average number of hours of employee } \\
\text { training (O|4) }\end{array}$ & 0.0452 & 11 & 0.0453 & 11 \\
\hline & $\begin{array}{l}\text { The number of guidelines for occupational health } \\
\text { and safety and employee health care (OI5) }\end{array}$ & 0.0326 & 15 & 0.0325 & 15 \\
\hline \multirow{5}{*}{$\begin{array}{l}\text { Environmental } \\
\text { factors (EF) }\end{array}$} & The level of safety technologies (EI1) & 0.0962 & 3 & 0.0967 & 3 \\
\hline & The level of implementation of legislation (EI2) & 0.0541 & 6 & 0.0545 & 6 \\
\hline & $\begin{array}{l}\text { The number of implemented voluntary standards } \\
\text { (EI3) }\end{array}$ & 0.0459 & 10 & 0.0462 & 10 \\
\hline & $\begin{array}{l}\text { The number of available databases on accidents } \\
\text { (EI4) }\end{array}$ & 0.0377 & 13 & 0.0379 & 13 \\
\hline & The amount of available funds (EI5) & 0.0180 & 18 & 0.0182 & 18 \\
\hline
\end{tabular}

Based on these results, we can conclude the following:

Occupational safety is primarily based on the estimated risk. The criteria 'costs' and 'social responsibility' are much less important than the 'risk' criterion (Table 7).

1. In relation to the risk, human and organisational factors are dominant, followed by technical factors, while environmental factors are the least important (Table 8). In relation to the costs, technical factors are the most important, followed by organisational factors and environmental factors, while human factors are the least important (Table 9). Organisational factors and environmental factors are dominant in relation to social responsibility, followed by human factors and, finally, technical factors (Table 10).

2. Regarding the final sub-criteria priorities, organisational factors are the most important, followed by environmental, human, and technical factors (Table 15).

3. Among the technical indicators, the most important indicator is the number of safety levels; among the human indicators it is the degree of compliance with operating procedures; among the organisational indicators it is the efficiency of safety resources management; and among the environmental indicators it is the level of safety technology (Table 16).

4. And regarding the final alternative priorities, the following are the most important: the efficiency of safety resources management; the number of workplace safety controls in practice; the level of safety technology; the degree of compliance with operating procedures; and the share of jobs with higher risk. 


\section{CONCLUSION}

Indicators of occupational safety quantitatively or qualitatively describe and measure specific effects, contributions, and results that are achieved in the safety system. The results of analysing these indicators are the basis for decision-making in the process of occupational safety management. Therefore, they should be meaningful, informative, and measurable, and should reflect the opinion of the decision-makers according to different states of the occupational environment.

From the perspective of occupational safety, it is important to monitor leading indicators, since they indicate the quality of activities that can prevent adverse outcomes (accidents and injuries). In this way, they identify the existing gaps and initiate decisions about their elimination.

The case study shows that lagging indicators are not among the best-ranked indicators in road construction companies in Serbia. The top-ranked lagging indicator, 'rate of occupational injuries', is in eighth place. Directing activities to continuous monitoring, and optimising the values of leading indicators, leads to the minimisation of the value of lagging indicators, which is the main objective of managing occupational health and safety. According to the results of this case study, reducing accidents and injuries in road construction companies can be influenced by increasing the efficiency level of resource management, increasing the number of workplace safety controls in practice, increasing the level of occupational safety technologies by following the operating procedures, and by decreasing the share of jobs with higher risk.

In this paper, the ranking of occupational safety indicators is based on the fuzzy AHP method. The ranking of occupational safety indicators can be also done by applying the interval AHP method, some other multi-criteria methods (e.g. TOPSIS, ELECTRE, PROMETHEE), or the combination of several methods (e.g. AHP and goal programming, or AHP and TOPSIS).

Proper definition of the key occupational safety indicators, their ranking by application of modern ranking methods, and continuous monitoring and improvement of the value of the highest ranking indicators help to improve the quality of the occupational safety system and, accordingly, the competitiveness of the organisation. Further research will be focused on quantifying the impact of safety on the efficiency of road construction companies, and the design and development of different decision-making procedures under fuzziness for the presented model.

\section{ACKNOWLEDGEMENTS}

This study is a part of the research projects III 44006 and III 42006, under the auspices of the Ministry of Education and Science, Republic of Serbia. The authors would also like to thank the experts from the Institute for Quality of Working and Living Environment '1. Maj' in Niš.

\section{REFERENCES}

[1] OSHA. 2012. Injury and illness prevention programs. White Paper, http://www.osha.gov/ dsg/topics/ safetyhealth/ OSHAwhite-paper-january2012sm. pdf

[2] International Labour Organization. 2003. Safety in numbers - Pointers for global safety culture at work. http:// www.ilo. org/wcmsp5/ groups/ public/ ---ed_protect/ ---protrav/ ---safework/ documents/ publication/wcms_142840.pdf

[3] EU-OSHA. Business aspects of OSH. https://osha. europa.eu/ en/topics/business-aspects-of-osh/ index_html

[4] Fernandez-Muniz, B., Montes-Peon, J. \& Vazquez-Ordas, C. 2009. Relation between occupational safety management and firm performance. Safety Science, 47, pp 980-991.

[5] Dağdeviren, M. \& Yüksel, I. 2008. Developing a fuzzy analytic hierarchy process (AHP) model for behavior-based safety management. Information Sciences, 178 (6), pp 1717-1733. 
[6] Bunn, W. B., Pikelny, D. B., Slavin, T.J . \& Paralkar, S. 2001. Health, safety, and productivity in a manufacturing environment. Journal of Occupational and Environmental Medicine, 43(1), pp 4755.

[7] Biggs, H.C., Dingsdag, D.P., Kirk, P.J. \& Cipolla, D. 2009. Safety culture research, lead indicators, and the development of safety effectiveness indicators in the construction sector. Proceedings of the 5th International Conference on Knowledge Technology and Society, Huntsville, AL, USA.

[8] Shannon, H.S., Mayrc, J. \& Haines, T. 1997. Overview of the relationship between organizational and workplace factors and injury rates. Safety Science, 26, pp 201-217.

[9] Harms-Ringdahl, L. 2004. Relationships between accident investigations, risk analysis, and safety management. J ournal of Hazardous Materials, 11, pp 13-19.

[10] Cohen, A. 1977. Factors of successful occupational safety. J ournal of Safety Research, 9, pp 168178.

[11] Holmberg, J., Laakso, K., Lehtinen, E. \& Johanson, G. 1994. Safety evaluation by living probabilistic safety assessment and safety indicators. TemaNord 1994:614, The Nordic Council of Ministers, Copenhagen, Denmark.

[12] Grabowsky, M., Ayyalasomayajula, P., Merrick, J., Harrald, J.R. \& Roberts, K. 2007. Leading indicators of safety in virtual organizations. Safety Science, 45, pp 1013-1043.

[13] Hopkins, A. 2009. Thinking about process safety indicators. Safety Science, 47, pp 460-465.

[14] Louvar, J. 2010. Guidance for safety performance indicators. Process Safety Progress, 29, pp 387388.

[15] Øien, K., Utne, I. \& Herrera, I. 2010. Building safety indicators: Part 1 - theoretical foundation. Safety Science, 49, pp 148-161.

[16] Kongsvik, T., Almklov, P. \& Fenstad, J. 2010. Organizational safety indicators: Some conceptual considerations and a supplementary qualitative approach. Safety Science, 48, pp 1402-1411.

[17] Tam, C.M., Tong, T.K.L., Chiu, G.C.V. \& Fung, I.W.H. 2002. Non-structural fuzzy decision support system for evaluation of construction safety management system. International J ournal of Project Management, 20, pp 303-313.

[18] Chan, A., Kwok, W.Y. \& Duffy, V.G. 2004. Using AHP for determining priority in a safety management system. Industrial Management \& Data Systems, 104, pp 440-445.

[19] Lee, W.K. 2006. Risk assessment modeling in aviation safety management. Journal of Air Transport Management, 12, pp 267-273.

[20] Teo, E.A.L. \& Ling, F.Y.Y. 2006. Developing a model to measure the effectiveness of safety management systems of construction sites. Building and Environment, 41, pp 1584-1592.

[21] Bozbura, F., Beskese, A. \& Kahraman, C. 2007. Prioritization of human capital measurement indicators using fuzzy AHP. Expert Systems with Applications, 32, pp 1100-1112.

[22] Kulak, O., Durmusoglu, B. \& Kahraman, C. 2005. Fuzzy multi-attribute equipment selection based on information axiom. J ournal of Materials Processing Technology, 169, pp 337-345.

[23] Øien, K. 2001. A framework for the establishment of organizational risk indicators. Reliability Engineering \& System Safety, 74, pp 147-167.

[24] Bergh, V.D. 2003. Leading and trailing indicators: Occupational safety. ISSA/Chamber of Mines Conference 2003 - Mines and Quarries Prevention of Occupational Injury and Disease, Sandton Convention Centre, Sandton, South Africa.

[25] J anackovic, G., Savic, S. \& Stankovic, M. 2011. Multi-criteria decision analysis in occupational safety management systems. Proceedings of the XVI Conference on Man and Working Environment, STS 2011, University of Nis, Nis, Serbia, pp 107-113.

[26] J anackovic, G., Savic, S. \& Stankovic, M. 2011. Safety performance indicators in organizational safety management systems. Proceedings of the 2nd International Conference Life Cycle Engineering and Management, DQM Research Centre, Belgrade, Serbia, pp 131-139.

[27] J oubert, W., Cruywagen, J.H. \& Basson, G.A.J. 2005. Will the implementation of a total quality management system benefit South African construction companies? South African Journal of Industrial Engineering, 16(1), pp 29-40.

[28] Saaty, T.L. 1980. The analytic hierarchy process. New York: McGraw-Hill.

[29] Srdjevic, B. \& Medeiros, Y. 2008. Fuzzy AHP assessment of water management plans. Water Resources Management, 22, pp 877-894.

[30] Chang, D.Y. 1996. Applications of the extent analysis method on fuzzy AHP. European J ournal of Operational Research, 95, pp 649-655.

[31] Chadaja, N. \& Podosenova, N. 2008. Safety management. Moscow: CentrLitNefteGaz. (In Russian)

[32] Liou, T.S. \& Wang, M.J . 1992. Ranking fuzzy numbers with integral value. Fuzzy Sets and Systems, 50, pp 247-256. 